\title{
PHILOSOPHY AND STRUCTURE OF THE ACADEMIC TEACHING IN PEDAGOGY TO PREVENT DROP OUT BY STUDENTS
}

\author{
Sandra Chistolini, PhD \\ Università degli Studi Roma Tre, Italy
}

\begin{abstract}
The mortality of university students requires actions in order to contrast this phenomenon and increase the attractiveness of the higher study. Pedagogy is one of the subject under siege in the sense that a considerable number of students tend to avoid or postpone the exam. After an empirical study conducted in 2006, contents and methodology of teaching were changed with the intend to meet the cultural expectations of the students. The article is critical report of this new experience of teaching in that subject in the context of university education of teachers. The main purpose is to demonstrate why and how the permanent and positive communication between teacher and students is the most important factor to implement the right to study and to divulgate knowledge. The structure of the teaching and learning process includes study of classics and scientific research with the aim to link theory and praxis. Conclusion underlines the urgency of modernisation of teaching as pivotal to lead young people to be responsible persons in the design of their future, in tune with the most recent European recommendations.
\end{abstract}

Keywords: Pedagogy, Higher education, Modernisation, Communication, Philosophy of teaching

\section{Introduction}

The Education of teachers at the Università degli Studi Roma Tre (Italy) lasts five years and includes General Pedagogy and Intercultural and Citizenship Education, as basic disciplines. General Pedagogy must be studied at the first year and Intercultural and Citizenship Education at the third year.

During the academic year 2006-2007 a fact was quite clear: students were not interested in General Pedagogy and the exam was postponed even though it was compulsory at the first year of the curriculum. A survey was conducted in order to understand how to change teaching and how to 
encounter the expectations of the students. It was also necessary to prevent the same critical situation for the third year.

A new structure of teaching of General Pedagogy has progressively been introduced with this characteristics: a) explanation of the aims of the entire process of study; b) interactive methodology; c) permanent use of the teacher's website; d) frequent appreciations of the results achieved by the students; d) renovation of the content of the curriculum; e) immediate feedback for each section of the programme; f) international exchange; e) balance between pedagogic theory and educational practices; g) development of the curriculum with imagination and creativity. Teaching became more organic and it combined humanistic studies with the active participation of students, tutors and colleagues. The whole philosophy was to consider the student a life member of the process and to encourage motivated interaction. It was important to discuss step by step of the curriculum and to be flexible and change again in case of the insurgent obsolescence of contents and tools. Students could evaluate teaching vision and perspective of learning and they were not just a passive target of the curriculum.

At the present, communication is constant and updated on the website, where there are teaching and workshops programmes in Italian and English, the teaching methodology is presented, and where also appear power point publications of lessons and international meetings with colleagues, who are invited to participate in academic lessons and interact with the students. Daily information for the semester remains available and it is then replaced by new information. The website is continuously update, keeping with current needs, hereby attempting to reach, above all, those students who cannot attend classes and would be isolated without that tool off communication. Also published in the personal site of the teacher are the results of written tests. Each academic year 300 students of General Pedagogy and 300 students of Intercultural and Citizenship Education follow the whole system of teaching and learning. To avoid dispersion an identifying number is assigned to each student, this allows to publish the data relative to the individual performance and to communicate in the respect of the legal rule about privacy. Students feel that teacher is caring for each of them, as person, and the result of that caring environment is their success with the increasing interest for the discipline.

\section{Sharing knowledge with classics and research}

The theory regarding the study of the classics of Pedagogy concerns the implementation of theoretical principles along the lines of national, European and international approaches towards education. Each student is required to study a classic which must be borrowed from the library and 
must to become familiar with the library system, moreover learns how to use this cultural resource in autonomy.

Three hundred students study authors of literature on teaching and make a power point presentation of it to the entire class. Teaching programmes are organised to permit the shared enrichment of theoretical validation through qualitative and quantitative research carried out within international teams. Participating in the research are university colleagues, students and active primary and secondary school teachers. At the conclusion of each research, the results are presented in a conference. The European dimension of teaching is constant as regards the Erasmus mobility, the European network of CiCe Children's Identity and Citizenship in Europe, and CiCea Children's Identity and Citizenship European Association. An example of this teaching + workshop + research + international exchange is the seminar programme carried out with Seton Hall University (USA). A university cooperation agreement was signed and the following activities were combined:

- teaching and workshop concerning pedagogy, interculture and citizenship;

- Daphne III, European research on children exposed to violence against their mother;

- training courses with teachers and students who participated in the Daphne III research $\mathrm{PhD}$;

- Master's in Education.

Participating in the seminar were: Italian and U.S. university students; public school teachers and principals; PhD and Master's students.

The methodology created in this teaching experience is defined as M.I.T.E Multiple Interaction Team Learning a composite development of knowledge.

\section{Concrete examples of what teacher has accomplished and learned}

Through ongoing and joint scientific research, teacher has learned to define problems and search for agreement with the students about the best methods for meeting their learning needs and expectations of human, social, cultural and professional growth.

Each year steadily increased the number of students who passed exam and followed workshops in General Pedagogy, as can be seen in figures from 1 to 3 . 
Fig. 1- General Pedagogy 2006-2014

Number of Students who passed exam and attended workshop

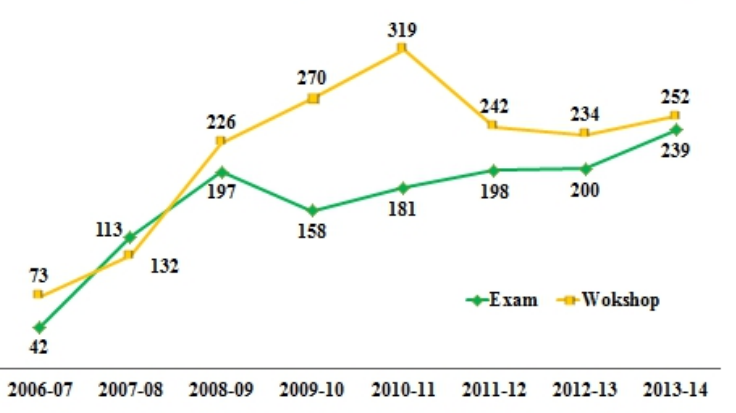

Fig. 2 - General Pedagogy 2006-2014

Students who passed the exam (\%)

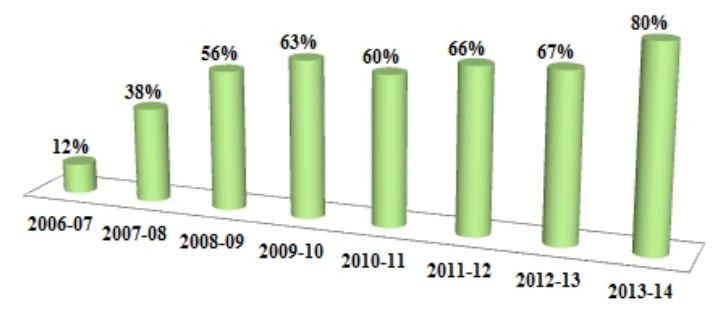

Fig 3 - General Pedagogy 2006-2014

Students who attended the workshop(\%)

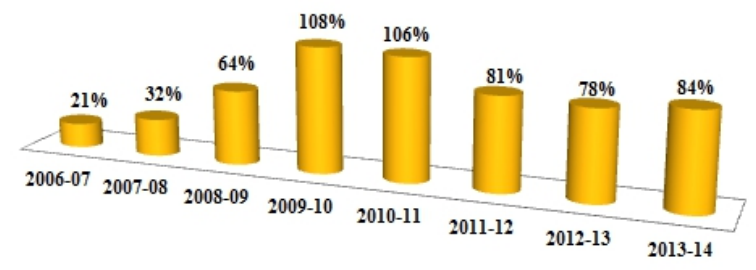


Concrete examples of what has been accomplished are also the creation of the Fondo Birmingham, foundation for intercultural education, and the Fondo Pizzigoni for the study of children's production according to experimental Renewed School of Giuseppina Pizzigoni, pedagogist contemporary of Maria Montessori. The material gathered is digitalised, catalogued and on-line. It has been learned how to systematise research and set up a concept of museum. Original video on educational ethnomethodology were realized with colleagues from Germany and France.

The school-university links created between Italy and Europe are still available in the multimedia section of the website.

\section{Approaches to teaching and philosophy of teaching}

The philosophy of teaching is humanistic, personalistic, active and interactive. The roots of theoretical teaching refer to Authors such as Erasmus of Rotterdam, Giambattista Vico, Johann Heinrich Pestalozzi and Emmanuel Mounier; as regards methodology, it follows the path of modern historicism (Benedetto Croce, Giuseppe Lombardo Radice and Wilhelm Dilthey), active school (Maria Montessori and Giuseppina Pizzigoni) and symbolic interactionism (John Dewey, Jerome S. Bruner, Herbert Blumer and Norman K. Denzin). From the past to the present time the red line is drawn by the freedom of learning in a meaningful context of teaching governed by interest and by curiosity for knowing. The discovery of the freedom of knowing leads to mastery of oneself. In this active process are essential interpersonal relationship and attention to situations of real life.

The main purpose of teaching is to render the university an environment of knowledge, research and innovation. Task of each student is also to write an own Manual of General Pedagogy (MGP), which relates his/her enrichment through study, research, workshop and knowledge. The students describe their personal courses of study, interaction with the teachers and fellow students and with the learning environments. They outline the knowledge achieved and that will be useful from an educational point of view as persons and teachers. The MGP is unique and remains the property of the student. It is presented in class prior to the oral exam and forms part of the final evaluation.

In 2013-2014 the classroom presentation in front of the class started with the Humanism of Erasmus of Rotterdam. We noted how the reasons for peace education are related with the intercultural issue. Value training, such as mutual respect, is a democratic reply to everyone's human needs and, more specifically, a reply to situations in which possible conflicts are detected as a result of the difference between the wish for active participation and the real possibilities of becoming part of a community, the integration into which sometimes requires a long time for acceptance. The meeting of different cultures is created through the communication of values that find 
the right ambience for manifesting themselves in school; children are introduced to knowledge about the personal and group histories through which behaviours of mutual respect, attention to others and education to human solidarity are fostered. Teachers who have experiences of interculture and international education within their university training and combine this experience with the methodological innovation offered by the course teacher show a higher degree of satisfaction in their studies, participate with enthusiasm and steer their learning towards preparation for the teaching role at school. The appreciation of studying increases when students participate in methodological decisions, know the course route and are successful in the test evaluations.

In order to know at what point intercultural education in Italian primary schools stands today, a short survey has been taken jointly with university students attending the degree course in Primary Education Sciences. Some students are following both the first-year course on general Pedagogy and the third-year course on Intercultural Pedagogy and citizenship. The course on general Pedagogy is dedicated to the subject of peace education, with an exam on educational theory and actions for prevention and resolving conflicts at school. The course on intercultural education and citizenship has been dedicated to defining interculture in relation to matters of human rights, the migratory phenomenon, prejudice and re-conceptualisation of the meaning of interculture from the postsecond-war period to date, with specific reference to placing interculture in the discipline of international comparative studies.

\section{Objectives to improve the professional competence}

The survey had ten objectives combining professional culture and preparation to work in schools as teachers.

Using research elements to achieve excellence in teaching

- In the first place, topics were presented in the classroom, hereby encouraging the opening up of dialogue with the world outside the university, specifically national situations, with respect to which intercultural questions must necessarily be faced. For example, the landing of children at Lampedusa and their placement in the island schools has had to be confronted. This objective forms part of the theory that examines the school-world relationship, according to the experimental method of education of Pizzigoni's Renewed School.

Combining theory and practice, relevance and scholarly excellence

- In the second place, an endeavour was made to present the topics in the classroom, encouraging the opening up of dialogue with the world outside the university, specifically international situations. Colleagues from other institutions of higher learning and universities in Cyprus and Portugal 
were invited to present concepts and practices of interculture in their countries. This objective forms part of the theory that examines the preparation of courses of international pedagogy at university.

- In the third place, the possibility was offered to integrate theoretical studies with field experience, by submitting a short, open-response questionnaire to those teachers willing to collaborate. This objective forms part of the theory that examines the relationship of theory and practices in teaching and learning processes.

- In the fourth place, it is deemed important to have students come into direct contact with the intercultural experienced at school and related by the teachers, hereby supporting the exchange between school and university, and between active teachers and teachers in training. This objective forms part of the theory that examines the professional and intergenerational communication among teachers.

Applying innovative teaching methods

- In the fifth place, positive interaction was developed within the group both inside and outside the classroom hereby applying the M.I.T.E. method - Multiple Interaction Team Education. This objective forms part of the theory that examines symbolic interactionism as a time of learning significant, cultural symbols.

- In the sixth place, the students were given the chance to directly experience the qualitative research methodology, in both an initial and exploratory stage of application. This objective forms part of the theory that examines the one that Dewey calls inquiry-based learning and learning by doing.

Applying problem-based/problem-oriented

- In the seventh place, debate in the classroom was encouraged before, during and after the interviews with the teachers. The replies were compared to what could be deduced from a relevant, widespread part of the literature on intercultural education in Italy during the period of 19922013. This objective forms part of the comparative theory of problem approach.

Achievements in encouragement of critical thinking

- In the eighth place, the plan was to steer the study and research towards the intersection of peace and intercultural topics and organise the contents of the teachers' responses; understood from the first surveys was how they were combining educational actions in the commitment of schools to encourage education based on building up a society in which people can live together well. This objective forms part of the theory of training to critical thinking.

Sustained commitment to teaching excellence, rather than one-off 
- The ninth objective was to organise the entire itinerary within a logical thought structure, by articulating pedagogical theory and methodology of research.

- The tenth objective was to produce a written text, both autonomous and personal, where the matter studied and the results of the survey were stated. This objective forms part of the theory of the development of personal creativity.

\section{Future goals for teaching in higher education}

The next goals I wish to reach concern the quality of teaching and learning. A systematic agenda for achieving these goals is as follows:

- Modernise higher educational teaching in agreement with European recommendations (Vassiliou, 2013)

- Combine the knowledge of theoretical and practical pedagogy with online platforms in Italian and in English

- Form mind-sets favourable to teaching and humanistic studies through research and action

- Reduce drop outs and school-leaving through forms of attraction to studying and support the physically challenged by monitoring their needs and expectations

- Offer opportunities of communication and cooperation between schools and universities

- Promote international meetings

- Presentation of the results of the work methodology in international conference.

\section{Conclusion}

The modern challenge to academic teaching is to contrast drop out by students. Due to demotivation and lack of cultural interest a reasonable number of students cannot follow the pace of the study. As result of this fact some disciplines tend to be left behind especially discipline with moral and ethical aims such as Pedagogy. Having experimented the situation at the University of Rome Three, Italy, the change of teaching was the best way to motivate students to complete their curriculum in due time. During the academic years which run from 2006 to 2014 a good balance of study of classics, clear methodology of work, interactive relationship between teacher and students, low interference of external factors, concentration of interest, live understanding of education, precise schedule of work allowed students to reach the goal of the exams and to increase the attractiveness for the discipline. The success of the students in their academic performance is one of the most consistent with the recommendations of European efforts to 
broaden young people's participation in the knowledge society by providing them with the tools and skills for social and professional life.

\section{References:}

Blumer, H., Symbolic Interactionism: Perspective and Method. New Jersey: Englewoood Cliffs, 1969

Bruner, J. S., In Search of Mind. Essays in Autobiography, New York: Harper and Row,1983

Croce, B., Intorno all'idealismo attuale, Firenze: Libreria della Voce, 1914

Denzin, N. K., Denzin N. K., "Symbolic Interactionism and Ethnomethodology”, in Douglas J. D. (ed.), Understanding Everyday Life. Toward the Reconstruction of Sociological Knowledge, Chicago: Aldine, 1970, pp. 259-284

Dewey, J., Logic, the Theory of Inquiry, New York: Holt, 1938

Dilthey W., "Der Aufbau der geschichtlichen Welt in den Geisteswissenschaften”, III/2, iv, in Gesammelte Schriften, VII, Leipzig, Teubner, 1914

Erasmus, D., Querela pacis undique gentium eiectae profligataeque, Basil.: apud I. Frobenium, 1517

Lombardo Radice, G., Educazione e diseducazione, Roma-Firenze: Associazione per il Mezzogiorno e Bemporad, Marzocco, 1929

Montessori, M., The Montessori method : scientific pedagogy as applied to child education in "The children's houses", with additions and revisions by the author, translated from the Italian by Anne E. George; with an introduction by Henry W. Holmes, New York: Stokes, 1912

Mounier, E., Manifeste au service du personnalisme, Paris: F. Aubier, 1936 Pestalozzi, J. H., Schwanengesang, Stuttgart: Cotta,1826

Pizzigoni, G., Scuola nuova maestro nuovo scolaro nuovo, Milano: Opera Pizzigoni, 1937

Vassiliou, A., et al. (Eds.), European Commission, High Level Group on the Modernisation of Higher Education. Report to the European Commission on Improving the quality of teaching and learning in Europe's higher education institutions, June. Luxembourg: Publications Office of the European Union, 2013. Retrieved December 27, 2013, from http://ec.europa.eu/education/news/20130618_en.htm

Vico, G., Il metodo degli studi del nostro tempo, a cura di Biagio Loré, Firenze: La Nuova Italia, 1993 